Research Article - https://doi.org/10.46463/ijrss.788883

\title{
The Relationship of Physical Activity Level and Recreation Area*
}

\author{
Ulfet ERBAȘ***
}

\begin{abstract}
This research examines the relationship between the criteria that individuals, who use recreation areas as physical activity spaces, care about their choice of areas and their level of physical activity. 389 individuals who do physical activity in 6 different parks and recreation areas in Ankara voluntarily participated in the study. The data of the study were collected by the International Physical Activity Level Questionnaire (Short Form) and the Recreation Area Preference Factors Scale. International physical activity questionnaire (Short Form) Craig et al. (2003) and its Turkish validity and reliability study was conducted by Öztürk (2005). Recreation Area Preference Factors were developed by Gümüş and Alay (2017). It consists of 5 subdimensions and a total of 24 items and is in the 5-point Likert type. Distribution normality was tested by the Kolmogorov-Smirnov test. In the analysis of the data, besides descriptive statistics, Kruskal-Wallis $\mathrm{H}$ test and correlation analysis were used for data. The level of significance was accepted as $p<0,01.21 .8 \%$ of individuals who use parks and recreation areas are underweight according to body mass index, 29.57 are within the healthy weight range, $34.24 \%$ are overweight and $15.13 \%$ are obese individuals. The lowest correlation value of the sub-dimensions of physical activity level and recreation area preference factors was found in the "activity" sub-dimension $(\mathrm{r}=0.106)$; the highest correlation value was in the "Sportive diversity" sub-dimension $(\mathrm{r}=$ 0.401). There is a significant difference in the physical activity levels of the research group according to the frequency of participation in the recreation areas. The physical activity levels of the participants who visit the parks and recreation areas for 5 days or more per week are significantly higher than the individuals who visit the parks and recreation areas once a week or less.
\end{abstract}

Keywords - Physical activity, Recreation, Body Mass Index.

\section{Fiziksel Aktivite Düzeyi ve Rekreasyon Alanı İlişkisi}

\begin{abstract}
Öz
$\mathrm{Bu}$ araştırma rekreasyon alanlarını fiziksel aktivite mekânı olarak kullanan bireylerin alan seçimlerinde önemsedikleri kriterler ile fiziksel aktivite düzeyi arasındaki ilişkiyi incelemektedir. Araştırmaya Ankara'da 6 farklı park ve rekreasyon alanında fiziksel aktivite yapan 389 birey gönüllü olarak katılmıştır. Araştırmanın verileri Uluslararası Fiziksel Aktivite Düzeyi Anketi (Kısa Form) ve Rekreasyon Alanı Tercih Etkenleri Ölçeği ile toplanmıştır. Uluslararası fiziksel aktivite anketi (Kısa Form) Craig vd. (2003) tarafından geliştirilmiş ve Türkçe geçerlik güvenirlik çalışması Öztürk (2005) tarafından yapılmıştır. Rekreasyon Alanı Tercih Etkenleri ise Gümüş ve Alay (2017) tarafından geliştirilmiştir. 5 alt boyut ve toplam 24 maddeden oluşmaktadır ve 5'li likert türündedir. Dağılım normalliği Kolmogorov-Smirnov testiyle sınanmıştır. Verilerin analizinde betimsel istatistiklerin yanısıra, Kruskal-Wallis H testi ve pearson korelasyon analizi uygulanmıştır. Önem seviyesi p $<0.01$ olarak kabul edilmiştir. Park ve rekreasyon alanlarını kullanan bireylerin \% 21.8 'i beden kütle indeksine göre zayıf, 29.57'si normal, \%34.24'ü fazla kilolu ve \%15.13'ü şişman bireylerden oluşmaktadır. Fiziksel aktivite düzeyi ile rekreasyon alanı tercih etkenlerine ait alt boyutlarda en düşük korelasyon değerinin "aktivite" alt boyutunda (r=0.106); en yüksek korelasyon değerinin ise "Sportif çeşitlilik" alt boyutunda olduğu $(\mathrm{r}=0.401)$ görülmektedir. Araştırma grubunun rekreasyon alanlarına katılım sıklığına göre fiziksel aktivite düzeylerinde anlamlı farklılık bulunmaktadır. Katılımcıların park ve rekreasyon alanlarını haftada 5 gün ve daha fazla ziyaret eden bireylerin fiziksel aktivite düzeyleri haftada 1 gün ve daha az ziyaret eden bireylerden anlamlı derecede fazladır.
\end{abstract}

Anahtar Kelimeler — Fiziksel aktivite, Rekreasyon, Beden Kütle İndeksi.

*This paper was presented at the $7^{\text {th }}$ International Euroasia Congress on Scientific Researches and Recent Trends December 6-9, 2020. Baku/ AZERBAIJAN

**Şırnak University, School of Physical Education and Sports, Şırnak-Turkey, e-posta:ulfeterbas@gmail.com https://orcid.org/0000-0002-6507-3046 


\section{INTRODUCTION}

With the development of technology and increase in urbanization, masses walking gradually shorter distances and participating less in outdoor activities are drifting towards sedentary life due to their busy working hours. Health problems caused by inactivity resulting from sedentary life have led people to recreation areas for physical activity and recreation, and these areas have become increasingly important (Gavand et al., 2019; Nagata et al., 2020; Jongenelis et al., 2018).

Physical activity is defined as any body movement produced by skeletal muscles that requires energy. It can be performed in such many different ways as walking, cycling, sports and active recreation (dance, yoga, tai chi). Some activities are voluntary and for recreation, while others may be necessary physical activities related to work and home. It may not provide the same mental or social health benefits compared to active recreation. According to the World Health Organization (2010), physical activity can provide health benefits if it is done regularly and in a sufficient time and intensity. Regular physical activity is a good protective factor for the prevention and treatment of common noncommunicable diseases, namely heart disease, stroke, diabetes, breast and colon cancer. It also contributes to the prevention of other important risk factors such as hypertension, overweight and obesity and is associated with good mental health, delayed onset of dementia, improved quality of life and well-being. Physical activity can and should be integrated into the environments where people live, work, and play. Walking and cycling are important means of transport and make it possible to participate in regular physical activity on a daily basis, but their role and popularity is declining in many countries (WHO, 2018).
As countries develop economically, their level of inactivity increases. In some countries, inactivity levels are up to $70 \%$ due to transportation, increased use of technology and urbanization (WHO, 2018). Insufficient physical activity is one of the most important factors in the emergence of non-communicable diseases and is responsible for approximately $9 \%$ of premature deaths worldwide (Smith et al. 2017). Physical inactivity increases the risk and severity of several chronic diseases. National sources recommend moderate-intensity physical activity for children and at least 150 minutes of physical activity per week for adults. Moderate-intensity physical activities are beneficial in routines such as daily brisk walking. Vigorous physical activities such as running, football and playing tennis are usually performed in leisure time (Han et al., 2013).

Use of leisure time where physical activity takes place in our lives, physical activity for recreational purposes in workhome environment and transportation areas and "public open and green spaces" as venues where the activity takes place constitute the supportive physical environment that provides the most important and widespread effect on the basis of "life-long", "health for all" within the scope of preventive health services, which have also been emphasized by world health policies (Soyer et al., 2019; Şimşek \& Çağlayan, 2019).

Physical activity possibilities of individuals, ease of transportation, characteristics of the environment they live in, interests and abilities significantly affect their physical activity levels and physical activity preferences (Tolukan \& Y1lmaz, 2014; Craig et al., 2003). Neighborhood parks are the recreational and social focal points of communities. Parks provide opportunities for individual users as remarkable facilities (walking 
paths, tennis courts, basketball courts) where people can be active on their own and as a meeting place for social groups and clubs to organize competitions, exercises and physical activities (Han et al., 2013; Reis, 2020; Evenson et al., 2016; Kaufman et al., 2019). Parks, which are one of the most important recreational areas that facilitate or prevent participation in physical activity, especially in the urban environment, should be investigated in terms of design and planning criteria within the city.

For this reason, determining the relationship between the criteria that individuals who use recreation areas as physical activity spaces and the level of physical activity and determining the factors that restrict the users in this area, provided that these are taken into account in the modernization of recreational areas based these criteria and in the construction of new areas, can increase the satisfaction level of the users of the new areas. In this context, the purpose of this study is to examine the relationship between the criteria taken into consideration by individuals who use recreation areas as physical activity spaces and their physical activity levels.

\section{METHOD}

\section{Study Group}

A total of 411 people living in Ankara between the ages of 18-73, determined by the appropriate sampling method, voluntarily participated in the study. By the exclusion of the missing or incorrectly filled scales in the study, the study group consisted of 389 individuals [49\% (190) females, 51\% (199) males].

\section{Data Collection Tools}

In order to reveal the demographic characteristics of the participants, the personal information form prepared by the researcher, the "International Physical
Activity Level Questionnaire (Short Form)" and the "Recreation Area Preference Factors Scale" were used.

International Physical Activity Level Questionnaire (IPAQ)

The Turkish validity and reliability of the scale developed by Craig et al. (2003) was carried out by Öztürk (2005).

In IPAQ, a criterion is that physical activities should be done for at least 10 minutes at a time. The survey questions whether the following were conducted within he last 7 days:

- Duration of vigorous physical activity (football, basketball, aerobics, fast cycling, weight lifting, carrying loads, etc.) (in minutes).

- Duration of moderate physical activity (light load carrying, cycling at normal speed, folk dance, dance, bowling, table tennis, etc.) (in minutes).

- Walking and one-day sitting times (in minutes).

Total physical activity score (MET$\mathrm{min} /$ week) is calculated by converting vigorous, moderate activity and walking times into MET corresponding to basal metabolic rate with the following calculations (Craig et al., 2003).

Walking score (MET-min/wk) = 3.3 *walking duration*walking days

Moderate activity score $($ MET-min/wk) = $4.0 *$ moderate activity duration*moderate activity days

Vigorous activity score (MET-min/wk) = 8.0 *duration of vigorous activity*vigorous activity days

Total Physical Activity Score $($ METmin $/$ wk $)=$ Walking + Moderate activity + Vigorous activity scores.

While physical activity levels of participants are classified as "low, medium and high" based on the total physical activity score; 
Physical Activity Levels:

1. Inactive level: Below 600 MET$\mathrm{min} /$ week.

2. Minimal active level: Between 600$3000 \mathrm{MET}-\mathrm{min} /$ week.

3. Very active level: Over 3000 MET$\mathrm{min} /$ week.

Recreation Area Preference Factors Scale (RAPF)

Developed by Gümüş and Özgül (2017), the RAPF consists of 5 sub-dimensions namely Sportive Diversity (SD), Staff (S), Location (L), Physical Facilities (PF) and Activity (A) and a total of 24 items and it is 5-Point Likert Scale type (1: Not Important At All, 5: Very Important). There are no reverse scored items in the scale. Internal consistency coefficients of the scale were calculated as 0.86 for Sportive Diversity, 0.81 for Staff subdimension, 0.73 for Location subdimension, 0.86 for Physical Facilities and 0.41 for Activity sub-dimension.

\section{Data Analysis}

Data was done in computer environment using the 22 SPSS (Statistical Package for Social Sciences) package program. Frequency and percentage analysis were used in descriptive data analysis. Distribution normality was tested by the Kolmogorov-Smirnov test. The Kruskal Wallis-H tests were used for data that did not show normal distribution. Pearson Correlation analysis was used to assess the relationship between variables.

\section{RESULTS}

Table 1. Physical activity levels of the participants based on gender

\begin{tabular}{lcccccc}
\hline \multirow{2}{*}{\begin{tabular}{l} 
Physical Activity \\
\cline { 2 - 7 }
\end{tabular}} & $\mathbf{F}$ & $\boldsymbol{\%}$ & $\mathbf{F}$ & $\boldsymbol{\%}$ & $\mathbf{F}$ & $\%$ \\
\hline Inactive & 32 & 16.8 & 42 & 21.1 & 74 & 19.6 \\
\hline Moderate Level & 122 & 64.2 & 117 & 58.8 & 239 & 61.4 \\
\hline Active & 36 & 19 & 40 & 20.1 & 76 & 19 \\
\hline Total & 190 & 100 & 199 & 100 & 389 & 100 \\
\hline
\end{tabular}

As seen in Table 1, according to the results obtained in the study, it was determined that $19.6 \%$ of the participants were at inactive, $61.4 \%$ were at moderately active and $19 \%$ were at active levels. In general, it can be said that the physical activity levels of males and females were close to each other. 
Table 2. Physical activity level and recreation area preference relationship

\begin{tabular}{|c|c|c|c|c|c|}
\hline & $\begin{array}{c}\text { Physical } \\
\text { Activity Level }\end{array}$ & $\begin{array}{l}\text { Sportive } \\
\text { Diversity }\end{array}$ & Staff & Location & $\begin{array}{l}\text { Physical } \\
\text { facilities }\end{array}$ \\
\hline $\begin{array}{l}\text { Sportive } \\
\text { Diversity }\end{array}$ & \multicolumn{2}{|l|}{$.401^{* *}$} & & & \\
\hline Staff & $.188^{* *}$ & $.251^{* *}$ & & & \\
\hline Location & $.311^{* *}$ & $.249^{* *}$ & $.232^{* *}$ & & \\
\hline $\begin{array}{l}\text { Physical } \\
\text { Facilities }\end{array}$ & $.259^{* *}$ & $.242^{* *}$ & $.253^{* *}$ & $.301^{* *}$ & \\
\hline Activity & $.106^{* *}$ & $.122^{* * *}$ & $.304^{* *}$ & $.220^{* *}$ & $.304^{* *}$ \\
\hline \multicolumn{6}{|l|}{${ }^{* *} \mathrm{P}<0.01$} \\
\hline \multicolumn{3}{|c|}{$\begin{array}{l}\text { When Table } 2 \text { is examined, it is seen that } \\
\text { in the sub-dimensions of physical activity } \\
\text { level and recreation area preference } \\
\text { factors, the lowest correlation value is in } \\
\text { the "activity" sub-dimension ( } \mathrm{r}=0.106) \\
\text { and the highest correlation value is in the }\end{array}$} & \multicolumn{3}{|c|}{$\begin{array}{l}\text { "Sportive diversity" sub-dimension } \\
(\mathrm{r}=0.401) \text {. Although there are significant } \\
\text { correlations between dimensions, it is } \\
\text { seen that they are low and medium in } \\
\text { value. }\end{array}$} \\
\hline
\end{tabular}

Table 3. Results of the Kruskal-Wallis H Test based on the level of physical activity and the frequency of participation in the recreation area

\begin{tabular}{|c|c|c|c|c|c|c|}
\hline & Groups & $\mathrm{n}$ & row avg. & $x^{2}$ & $\mathrm{sd}$ & $\mathrm{p}$ \\
\hline \multirow{3}{*}{$\begin{array}{l}\text { Physical activity } \\
\text { level }\end{array}$} & Week $1<$ & 139 & 149.97 & \multirow{3}{*}{5.05} & \multirow{3}{*}{2} & \multirow{3}{*}{.043} \\
\hline & Week 2-4 & 171 & 168.21 & & & \\
\hline & Week 5> & 79 & 198.84 & & & \\
\hline
\end{tabular}

${ }^{* * *} \mathrm{P}<0.01$

Table 3 depicts how the results of the Kruskall Wallis H-test indicated that there is a significant difference in the physical activity levels of the research group based on frequency of participation in recreation

areas. Physical activity levels of the participants who visit the parks and recreation areas for 5 days or more per week are significantly higher than those of the individuals who visit those places 1 time or less per week.

Table 4. Distribution of BMI groups based on the physical activity levels of the participants

\begin{tabular}{lcccccccccc}
\hline BMI & \multicolumn{2}{c}{ Underweight } & \multicolumn{2}{c}{$\begin{array}{l}\text { Healthy } \\
\text { Weight }\end{array}$} & \multicolumn{2}{c}{ Overweight } & \multicolumn{2}{c}{ Obese } & \multicolumn{2}{c}{ Total } \\
\hline IPAQ & $\mathbf{N}$ & $\%$ & $\mathbf{N}$ & $\mathbf{\%}$ & $\mathbf{n}$ & $\boldsymbol{\%}$ & $\mathbf{n}$ & $\mathbf{\%}$ & $\mathbf{n}$ & $\mathbf{\%}$ \\
\hline Inactive & 14 & 3.89 & 22 & 5.78 & 26 & 6.81 & 12 & 3.08 & 74 & 19.6 \\
\hline $\begin{array}{l}\text { Moderate } \\
\text { Level }\end{array}$ & 55 & 14.11 & 68 & 17.48 & 79 & 20.31 & 37 & 9.52 & 239 & 61.4 \\
\hline Active & 12 & 3.08 & 25 & 6.31 & 29 & 7.12 & 10 & 2.53 & 76 & 19 \\
\hline Total & 81 & 21.08 & 115 & 29.57 & 134 & 34.24 & 59 & 15.13 & 389 & 100 \\
\hline
\end{tabular}


In Table 4, BMI distributions of the participants based on their physical activity levels are given. Accordingly, $21.8 \%$ of the individuals who use recreation areas as physical activity places are underweight, 29.57 are healthy weight, $34.24 \%$ are overweight and $15.13 \%$ are obese individuals. According to the table above, $20.31 \%$ of overweight females who use parks and recreation areas do moderate physical activity.

\section{DISCUSSION AND CONCLUSION}

According to the findings of the research conducted in order to examine the relationship between the criteria that individuals, who utilize recreational areas offered to the public by local governments as physical activity spaces, care about in their field selection and the level of physical activity, it was determined that the participants attached the most importance to the "sportive diversity" and "location" sub-dimensions when choosing their recreation areas as physical activity places, while the sub-dimension with the lowest importance was the "activity" subdimension. In addition, positive significant relationships between low and moderate intensity were determined between all sub-dimensions of the recreation area preference factors scale and physical activity level.

According to the findings obtained from the research, among the criteria that individuals who use recreation areas as physical activity spaces pay attention to in their area-selection, the sub-dimension of sportive diversity takes the first place. When the items of the sportive diversity sub-dimension are examined, it is understood that the most important features that a recreation area should have are walking paths, enabling different sports branches and the availability of bicycle paths. In the items of the location sub-dimension, which is the second highest factor, the location of the recreation area and transportation facilities are mentioned. In other words, proximity of the park and recreation area to the house, being close to the city center and being accessible by public transportation is the second most important factor affecting the preferences of the participants. When the literature is examined, it is seen that similar results were obtained in previous studies (Kaczynski \& Henderson, 2007). Therefore, it is extremely important to consider the sub-dimensions of sportive diversity and location, which we have just mentioned, in order to ensure that the newly built recreational areas are used by more individuals as physical activity spaces (Smith et al., 2017).

In a study carried out to determine which environmental interventions at the local level increased the physical activity levels of residents, taking into account the cost of the intervention and the different ethnic and socioeconomic effects of the interventions, a systematic database search was conducted. As a result of this study, it has been determined that provision of walkability features and playgrounds in quality parks have positive effects on active access to, physical activity, visit or use of the environment (Smith et al. 2017). Similar study results were obtained when the literature was examined (Smith et al. 2017; Gümüş et al. 2018). 
Another finding of our study is that the factor with the lowest average in the area preferences of individuals who use recreation areas as physical activity spaces is the "activity" sub-dimension. Considering the criteria that individuals who use recreation areas as physical activity places care about in the selection of the area, we can conclude that the sportive diversity and the location of the recreation area are considered more important than socio-cultural activities to be held in this area such as concerts, festivals, symposiums, congresses etc. When we look at the literature studies, it is seen that similar findings were obtained (Koçak et al., 2017; Gümüş \& Özgül, 2017; Gümüş \& Koç, 2019).

It is observed that as the frequency of the participants to use the recreation areas as physical activity places increases, their level of physical activity also increases. In another finding of the study, the physical activity levels of the individuals who use the recreation areas of the research group as physical activity spaces were examined according to their participation frequency and a significant difference was found. It was observed that physical activity levels of the individuals who visit recreation areas for 5 days or more per week are significantly higher than those of the individuals who visit those places 1 time or less per week. It can be argued that as the frequency of the participants to use the recreation areas as physical activity places increases, their level of physical activity also increases.

According to another finding of our study, when the physical activity levels of the participants who use the recreation areas as physical activity places are examined, it was determined that $19.6 \%$ were at the inactive level, $61.4 \%$ were at the medium level and 19\% were at the active level. In general, it can be said that the physical activity levels of males and females were close to each other. In their study on the physical activity levels of desk workers, Vural et al. (2010) reported that $25.2 \%$ of them were not active, $48.9 \%$ were at a low active level and $25.9 \%$ were sufficiently active. Yilmaz (2019), in their study on high school students in the Gaziantep region, reported that the physical activity levels of female students are lower than male students, and that there is no significant difference between the time they spend for these activities and the number and frequency of the days they do activities based on gender. In studies conducted in the last five years considering the level of physical activity in young people, it is among the results that the physical activity levels of university students are quite low and their moderate physical activity score are higher than vigorous physical activity scores (Şavran Cengiz \& Delen, 2019).

When we look at the studies in the literature, it was found that men do more physical activity than women (Kaya et al., 2014; Vural, 2010; Şarvan Cengiz \& Delen, 2019; Y1lmaz, 2019). In this study we conducted, it is seen that generally the physical activity levels of males and females are close to each other. The reason for this can be attributed to the fact that there are more unemployed women than working women among park and recreation area users. 
According to the findings obtained in the study, when the BMI distribution according to the physical activity level of the participants is examined, $21.8 \%$ of the individuals using the parks and recreation areas are underweight, 29.57 are healthy weight, $34.24 \%$ are overweight and $15.13 \%$ are obese individuals. $20.31 \%$ of overweight females who use parks and recreation areas do moderate physical activity. Saatci (2019), in their study conducted to determine the physical activity levels of people between the ages of $18-69$, found that the BMI of $48 \%$ was within the healthy weight range, $52 \%$ of the participants were inactive and $42 \%$ were moderately active (Saatci, 2019). In our study, it is seen that the participants are predominantly overweight and have normal BMI. The reason for this can be attributed to the fact that park and recreation area users are heavily involved in losing weight.

In conclusion, in our study conducted with 389 volunteers aged between $18-73$ years in 6 different parks and recreation areas in Ankara in order to examine the relationship between the criteria that individuals who use recreation areas as physical activity places, and their physical activity levels, $21.8 \%$ of the individuals were underweight according to body mass index, $29.57 \%$ were within the healthy weight range, $34.24 \%$ were overweight and $15.13 \%$ were obese individuals and it is seen that the lowest correlation value in the sub-dimensions of the factors of physical activity and recreation area preference was in the "activity" subdimension while the highest correlation value was in "Sportive diversity" and "location" sub-dimensions. There is a significant difference in the physical activity levels of the research group based on the frequency of participation in the recreation areas and physical activity levels of the participants who visit the parks and recreation areas for 5 days or more per week were found to be significantly higher than those of the individuals who visit those places 1 time or less per week.

\section{REFERENCES}

Craig, C.L., Marshall, A.L., Sjöström, M., Bauman, A.E., Booth, M.L., Ainsworth, B.E., Pratt, M., Ekelund, U., Yngve, A., Sallis, J.F., \& Oja, P. (2003). International physical activity questionnaire: 12country reliability and validity. Med sci sports Exerc, 195(9131/03), 3508-1381.

Evenson, K. R., Jones, S. A., Holliday, K. M., Cohen, D. A., \& McKenzie, T. L. (2016). Park characteristics, use, and physical activity: A review of studies using SOPARC (System for Observing Play and Recreation in Communities). Preventive Medicine, 86, 153-166.

Gavand, K. A., Cain, K. L., Conway, T. L., Saelens, B. E., Frank, L. D., Kerr, J., \& Sallis, J. F. (2019). Associations between neighborhood recreation environments and adolescent physical activity. Journal of physical activity and health, 16(10), 880-885.

Gümüş, H., \& Özgül, S. A. (2017). Development of Scales for Barriers to Participation and Preference Factors in The Use of Recreation Area. Journal of Human Sciences, 14(1), 865-882.

Gümüş, H. \& Alay Özgül, S. (2017). Development of scales for barriers to participation and preference 
factors in the use of recreation area, Journal of Human Sciences, 14(1), 865-882.

doi:10.14687/jhs.v14i1.4448.

Gümüş, H., Ayna, Ç., \& Yıldırım, İ. (2018), Reviewing attitudes of women towards leisure activities in terms of different variables, Turkish Journal of Sport and Exercise, Volume: 20 - Issue: 3Pages: 224 -229, DOI: $10.15314 /$ tsed.491629.

Gümüș, H. \& Koç, M.C., (2019). Rekreasyon Alan Tercihi ve Psikolojik İyi Oluş, Spor Bilimleri Alanında Araştırma ve Derlemeler, p: 308-318, Gece Akademi Kitapevi, Ankara.

Han, B., Cohen, D., McKenize, L. Thomas, (2013). Quantifying the contribution of neighborhood parks to physical activity, Preventive Medicine, 57(2013), 483-487.

Jongenelis, M. I., Scully, M., Morley, B., Pratt, I. S., \& Slevin, T. (2018). Physical activity and screen-based recreation: Prevalences and trends over time among adolescents and barriers to recommended engagement. Preventive medicine, 106, 66-72.

Kaczynski, A. \& Henderson, K. (2007). Environmental Correlates of Physical Activity: A Review of Evidence about Parks and Recreation. Leisure Sciences, 29(4): 315-354.

Kaufman, T. K., Rundle, A., Neckerman, K. M., Sheehan, D. M., Lovasi, G. S., \& Hirsch, J. A. (2019). Neighborhood recreation facilities and facility membership are jointly associated with objectively measured physical activity. Journal of urban health, 96(4), 570-582.

Kaya, E., Sari, İ., Tolukan, E. \& Gülle, M. (2014). Examination of trait anxiety levels of physical education and sports students (Ibrahim Cecen
University case). Procedia-Social and Behavioral Sciences, 152, 399402.

Koçak, Y., Tukul, U., Tolan, B., Gümüş, H., \& Tolukan, E. (2017). Analysis of Expectations and Perceptions of the Customers in Sports and Healthy Life Centers for Service Quality (Sample of Afyonkarahisar Province). International Journal of Recreation and Sports Science, 1(1), 38-46. DOI: 10.46463/ijrss.368384.

Nagata, S., McCormick, B. P., \& Austin, D. R. (2020). Physical Activity as Treatment for Depression in Recreation Therapy: Transitioning from Research to Practice. Therapeutic Recreation Journal, 54(1).

Öztürk, M. (2005). A research on reliability and validity of international physical activity questionnaire and determination of physical activity level in university students. Master Thesis, Hacettepe University, Ankara.

Reis, A. C., Lokpo, K., Bojanic, M., \& Sperandei, S. (2020). In search of a "vocabulary for recreation": Leisure-time physical activity among humanitarian migrants in regional Australia. PloS one, 15(10), e0239747.

Saatci, M. (2019). The effect of number of meals, physical activity level and sleep levels on anthropometric measurements of adult individuals of 19-65 age group, Doctoral Dissertation, Bilgi University, İstanbul.

Smith, M., Hosking, J., Woodward, A., Witten, K., MacMillan, A., Field, A, Bass, P. \& Mackie, H. (2017), Systematic literature review of built environment effects on physical activity and active transport - an update and new findings on health equity, 
International Journal of Behavioral Nutrition and Physical Activity, 14:158 DOI 10.1186/s12966-0170613-9.

Soyer, F., Tolukan, E. \& Dugenci, A. (2019). Investigation of the Relationship between Leisure Satisfaction and Smartphone Addiction of University Students. Asian Journal of Education and Training, 5(1), 229235.

Şarvan Cengiz, Ş. \& Delen, B. (2019), Physical Activity Level in Young People, International Journal of Contemporary Educational Studies (IntJCES), December, 5(2): 110122.

Şimşek, F.M. \& Çağlayan A.Y. (2019). Kent Parklarının Fiziksel Aktivite Düzeyine Etkisi: İstanbul Sultanbeyli Gölet Parki Örneği, II. International Physical Education, Sport, Recreation and Dance Congress, April 20-21, syf:56-73, Alanya Alaaddin Keykubat University, Turkey

Tolukan, E. \& Yilmaz, B. (2014). Determining the Factors Which Can Prevent Recreational Participaion Of University Students Who Attend To The Departments According To Special Skill Exams. International Journal of Sport Culture and Science, 2(Special Issue 1), 525539.

Vural, Ö., Eler, S. \& Atalay Güzel, N. (2010). The Relation of Physical Activity Level and Life Quality At Sedentary Profession, Spormetre Beden Eğitimi ve Spor Bilimleri Dergisi, VIII (2), 69-75.

World Health Organization (2018), More Activite People for A Healthier World. Global Action Plan on Physical Activity 2018-2030.

Yılmaz, K.M. (2019), Comparison of Physical Activity Levels of High
School Students in Gaziantep, Master Thesis, Coaching Education Department Department of Motion and Training Science, İstanbul Gelişim University. 